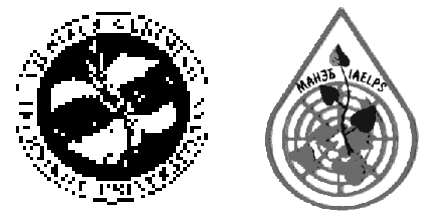

\title{
ON THE ENVIRONMENTAL POLLUTION PROBLEM: A REVIEW
}

\author{
Sunday Ayoola Oke \\ Dept of Mechanical Engineering, University of Lagos, Akoka-Yaba, Lagos, Nigeria. \\ Tel: (234-01) 49386379 Ext. 1114,E-mail: sa_oke@yahoo.com
}

Received 17 Feb 2004; accepted 28 May 2004

\begin{abstract}
The commercial sector of most industrialised economy accounts for a significant percentage of the total environmental pollution (EP) that we experience today. Recent advancements in EP research have therefore provided environmental regulators and health scientists with a wide array of solution techniques. Unfortunately, the EP literature has lagged behind in providing an up-to-date integrated stream of research that could be useful for new entrants and experienced researchers. The objective of the paper is to present a comprehensive review of EP research. The principal motivating factor is the deficiency of informative articles that reveal the length, breadth and depth of scientific investigations in the area. The study extends to a general survey, models, empirical studies and cases that have extended the frontier of knowledge in EP research. Our aim is to stimulate further empirical and theoretical developments in the EP area. A second intent is to argue that research into EP provides great potentials for increasing our knowledge regarding environmental management. The future holds promising results for researchers and practitioners engaged in EP research. Future studies are expected to save billions of dollars through development of novel cost-effective methods.
\end{abstract}

Keywords: environmental pollution, water, air, soil.

\section{Introduction}

The EP Literature has a long and distinguished history. The primary incentive for the high interests in EP problems is the need for improvement and realisation for a sustainable development in the environment. Recently, research on EP is gaining an increasing attention of professionals, scholars, and governments. The notable stakeholders in EP research are engineers, chemists, physicists, meteorologists, epidemiologists, lawyers, economists, sociologists, agronomists, and toxicologists, among others. Today, EP presents a big problem, a challenge, and a matter of deep interest and concern to citizenry, governments, and professionals. Consequently, governments in many countries worldwide have increased their devotion and currently making efforts in strengthening the prevention of EP. Environmental pollution threatens the safety of people's lives and wealth, and brings interrelated social problems. Thus, this has led to a huge investment of human intelligence and capital resources in the management and control of EP problems.

EP problems evolved in the $20^{\text {th }}$ century as a result of rapid economic development that was generated by the production activity in the manufacturing sector, giv- ing damage to the productivity of other sectors, including the agricultural sector. The literature defines EP as an unfavourable alteration of our surroundings through direct or indirect effect, resulting in changes in energy patterns, radiation levels, chemical and physical constitution of our environment, and abundance of organisms. These changes may affect humans directly or through their supplies of water, agricultural, and other biological products.

Most countries of the world that previously have had wonderful and untouched nature are now occupied with motor ways, sky scrappers, nuclear power stations, and smoking industrial plants. A number of irresponsible humans also destroy the natural ecosystem for their own profit. Unfortunately, today, this irreversible destruction of the base of existence is still being carried on with a fast speed. Another concern is the greenhouse effect caused by the release of carbondioxide to the environment. In China, for example, the signing of the UN climate change framework treaty indicates recognition of the need to control the exhaust of greenhouse gases, such as carbondioxide. The world is also committing itself to action to reducing pollution associated with energy use, including reduction of carbon dioxide. 


\section{Literature review}

The English language literature on EP classifies pollutants into two major groups: natural and artificial (Antonescu and Mateescu (2001)); Takahashi, et al (2000); Milton and Rahman (1999). Artificial pollutants result from human activity Takahashi, et al (2000). Natural pollutants are non-human induced Milton and Rahman (1999). Even in the artificial pollutants' group, we have two categories: completely artificial and substantially artificial. Examples of the first category are chlorinated hydrocarbons (such as DDT), and lead aerosols (from use of leaded gasoline). The second category includes oil in the oceans and phosphate in running Waley. There is also a substantial contribution of natural sources to pollution. Substances involved are hydrocarbons and sulphur oxides in the atmosphere, and radiation. Clearly, even if natural sources exceed artificial ones, the adverse effects might result largely from artificial sources in populated industrial areas.

\subsection{Air, water and soil pollution}

Three broads theoretical and empirical research steams (air, water, and soil) represents the EP literature. These major areas contain several hundreds of research papers with contributions from research institutions, universities, and government agencies.

\subsubsection{Air pollution}

Air pollution research is an important public health area. Epidemiological studies show that air pollution in developing countries accounts for tens of thousands of deaths and billions of dollars losses in medical costs and productivity every year Milton and Rahman (1999). A great many published papers have therefore appeared varying from reviews to rigorous analyses of specific problems, suitable for both the specialist and the academician. Forest decline and decreasing crop yield are generally thought to be caused by a combination of air pollutants such as acid depositions, $\mathrm{O}_{3}, \mathrm{SO}_{\mathrm{x}}, \mathrm{NO}_{\mathrm{x}}$, and other Oxidants.

Air pollutants such as $\mathrm{O}_{3}$ dramatically reduce the primary production of forests, since leaves exposed to large doses of $\mathrm{O}_{3}$ display the typical symptoms of mottling with decreasing photosynthesis and increasing dark respiration. To stimulate the change of the primary production by the air pollutants, various models have been developed for trees in which the dynamics or the cumulative frequency of short-term and/or long-term exposure of air pollutants has been considered (Vavrova, et al (2002)).

Some notable documentation on air pollution includes those by Takahashi, et al (2000), Abdel and Metwally, and Sabir et al (2003). These studies have an international dimension in collaborative research efforts between countries of the world on the subject. Air pollution research also extends to cover the iron and steal industries, livestock, and agriculture.
Takahashi studied air pollution in two countries (China and Japan) based on the iron and steel industry (coal and coke industries are contained). The preventive measures for environmental protection in China were reported. Co-generation system of clean energy and pig iron were proposed as a new process.

The investigation by Abdel and Metwally focused on cement production factories in Egypt. They assessed the air quality from the environmental and health point of view based on traces in dust particulate from cement industrial areas. The multi-elemental analysis has revealed that the cement factories are potential sources of danger and toxic pollutants with serious impacts on human health in the study area. Principally, the identified pollutants are suspended particulate and lead.

Sabir et al (2003) studied the daily contamination of the meat sold in the open market and roadsides that are consumed by people. The samples were analysed for the estimation of trace metals such as $\mathrm{Pb}, \mathrm{Cu}, \mathrm{Ni}$, and $\mathrm{Zn}$, along with $\mathrm{Ca}, \mathrm{Mg}$, and Fe. The overall concentration of $\mathrm{Pu}, \mathrm{Ni}, \mathrm{Zn}$, and $\mathrm{Mn}$ were found (0-4 ppm). Among major elements, Fe was found quite high (600$700 \mathrm{pmm})$. The $\mathrm{Ca}(600-2000 \mathrm{pm})$ and $\mathrm{Mg}\left(800_{-}\right.$ $1300 \mathrm{ppm}$ ) levels were also higher. Fe was recorded higher in beef and mutton. $\mathrm{Ca}$ in fish and mutton and $\mathrm{Mg}$ in mutton chicken and fish were comparatively high.

\subsubsection{Water pollution}

Research on water pollution has emphasised the risk of surface oil and other contaminants. A strong cry of this body of research has been the protection of water from pollution by contaminants. Prominent studies in the area of water pollution include Ahmed (1998), Lasut and colleague, and Ganjidoust (1998).

Ahmed focused on pure water pollution used for drinking and different other industrial purposes. He sought for pollution due to cadmium, lead, heavy and toxic metals in the water. Cadmium and lead was expected to be not more than 10 and $50 \mathrm{ng} / \mathrm{ml} \mathrm{levels} \mathrm{in}$ the water. An automatic voltametric method was used for measuring the pollution levels of these metals in the sample area. Lasut and colleague studied the marine and coastal zone EP and found a rapid increase in the quantity of pollution in marine and coastal waters.

Pollutants diminished the number of survivors, influenced metabolism and breeding efficiency, and altered behavioural patterns and effect structures and forms of the ecosystem. Clearly, pollutants can degrade the quality of environment and influence the resources. The work is a challenge to planners and designer of marine environmental management to avoid the degradation of the marine resources due primarily to the activities of exploitation of resources, which were not well managed.

Gankidoust (1998) advocated that the daily extractions of crude oil and gas and their transportation are the main pollution sources of the Caspian Sea which contains about 100000 million barrels of oil and over 35000 million cubic meters of flue gas. Many ships 
that navigate in the Sea emit pollution to the Sea which is surrounded by many cities and industries. Pollution from these cities and industries enter the Caspian Sea either directly or through rivers.

\subsubsection{Soil pollution}

Different directions have been used to investigate into soil pollution research. A direction is indicated in the principal study carried out by Ulukanligil et al on soil transmitted helminth (STH) infection in developing countries. They studied sewage farms, streams, and vegetables to determine the sources and routes of STH infection in Turkey. One hundred and eight-seven (59,5\%) of a total of 314 samples, including $88,4 \%$ of the stool samples, $60,8 \%$ of the water samples, $84,4 \%$ of the soil samples and $14 \%$ of the vegetable samples, were found to be positive for STH eggs. These results indicate that the soil and vegetables are heavily contaminated, and suggest a vicious circle between humans and the environment.

\subsection{Other dimensions of EP research}

Apart from the traditional respective of viewing EP research in terms of air, water, and soil, there are other numerous studies that did not fall directly into these classifications (see Jost and Quas (2001); Milton and Rahman (1999)). An example of this is the study of the relationship between urban population density and urban environmental problems. Jost and Quas (2001) investigated various types of EP in Mumbai, classified into problems related to air pollution, and, secondly, problems due to the lack of an adequate provision of local public goods such as sewage and refuse collection. It has been shown that this kind of environmental problem is closely related to high growth and density of population in Mumbai. Finally, the facts of Mumbai's population growth and EP were related to each other. Interrelations between population, development, and environmental damage were identified.

Another study investigated the influence of EP in evaluating the health condition of animal species as well as the risk factors affecting them. Specifically, Antoneseu and Mateescu (2001) studied the honey industry and the new exigencies faced due to the high sensitiveness of the raw material to a wide array of aggression factors.

Yet, in another study, NAA was investigated to precision analysis of metallic elements in a pine-needle. It was found that about twenty elements in a pine-needle could be simply analysed by NAA and a pine-needle could be suitable as a bio-monitor for the monitoring of EP in Korea.

Still on other aspects of EP research, Vavrova, et al. (2002) carried out a related work on contamination of ration components and roughage fed to dairy cows and finishing bulls in two different agricultural ecosystems. Materials used for analyses included irrigation water, grass growth, roughage, preserved feeds and trough samples of feed.

The mobile laboratory of Regional Hygienic Services measured emissions by high-resolution gas chromatography with election capture detection. The concentrations of indicator polychlorinated biphenyl (PCB) congeners did not exceed the safety limit in any of the sampling areas (mean concentrations of PCB in feed between 1-2 $\left.\mu \mathrm{g} \cdot \mathrm{kg}^{-1}\right)$. Calculation of the transfer co-efficient $Q$ proved to be a suitable tool for the assessment of residue transfer (dairy cows $0,2-1,0$ bulls $0,3-1,0$ ). Feed was identified as an important contamination source for animal tissues and milk.

Yet, in another study, Suga treats a comprehensive analysis of welfare in an open economy where there are two countries, two goods, one factor and the transboundary. It has been found that the transboundary rate of pollution from an agricultural good exporting country is sufficiently large and the non-transboundary rate of pollution in a manufacturing good exporting country is sufficiently small.

Rao (1996) adds to the empirical evidence supporting a significant connection between ethics and profitability by examining connection between published reports of unethical behaviour - in terms of EP by publicly traded US and multinational firms and the performance of their stock. The analysis has showed that the actual stock performance for those companies was lower than the expected market adjusted returns. Unethical conduct by firms that was discovered and publicised does impact on the shareholders by lowering the value of their stock for an appreciable period of time.

\section{Computers and environmental pollution}

The advent of the computer has brought tremendous progress in the study of EP. Today the EP researcher is in the midst of a dramatic revolution in scientific environmental investigations. Computers in general, and the use of Decision Support System (DSS) with a reference database appear destined to dominate soon the whole area of the EP research. The computer has emerged as one of the most revolutionary inventions of our time. This revolution has come about so abruptly that researchers and practitioners recognise a very real technological gap in their background and the need to overcome it.

The impact of the computer on the EP research is complex and many-sided. On the surface, an appraisal of the impact of the computer on the EP research bears some similarity to an appraisal of the audience in a movie theatre. A theatre can be judged to be half-full or halfempty depending upon the perspective of the perceiver. By the same token, the impact of the computer on the EP research can be judged to be considerable, if one takes into account the multiple manipulations of data which make electronic data processing possible and performable. 
Today data analysis in the EP research would be impossible without computers. Practitioners rely on the computer as an important and powerful tool for collecting, recording, retrieving, and analysing simple and complex problems as well as distributing tremendous masses of information in EP research. It saves countless years of tedious work of the EP researchers and practitioners. The computer removes the necessity to monitor and control tedious and repetitive processes. Despite the importance of computers, its potential is so little explored that its full impact is yet to be realised.

Having discussed the impacts of computers in the EP research, it is worth while reviewing a number of related computer documentation in the EP research. A prime paper that comes to mind is the work by $\mathrm{V}$. de Oliveria et al (2001) who developed an intelligent decision support system (DSS) applied to EP caused by swine manure. The DSS allows the identification of high pollution risk producers and pollution sources. It has useful information to restrict the issue of new swine production licenses in high-risk areas, and to identify current producers that must improve their waste management system thus reducing pollution. The system may also be used to simulate the consequences of changes in animal density and management techniques on the severity of pollution (what-if analysis). The system gives support to technicians, researchers, and environmental organisations for making decisions on pollution issues involving swine production.

Another useful study was carried out by Diamantoukos on the application of computer simulation to the estimation of the EP costs of an inactive hazardous waste site. The models of the pollution costs simulation model (PCSW) were described which trace the flow of costs from remedial action at EPA and state administered sites through to insureds in the form of potentially responsible parties (PRPs) and finally to the application of coverage defences. Results were presented including the characterisation of variability and comparisons to published insurance industry estimates of ultimate loss and expenses.

In attempts to solve the ever-increasing complexity and uncertainty involved in real-world environmental pollution problems researchers have sought to apply different soft computing techniques in environmental pollution control. Soft computing represents a collection of emerging problem solving to technologies including fuzzy logic, probabilistic reasoning, neural networks, and evolutionary algorithms. Much progress has been recorded in this area, since soft computing technologies allow us to use empirical prior knowledge and unprecise data to build approximate environmental pollution models. Soft computing also provides it with a set of flexible computing tools to perform approximate reasoning.

Primarily, the area of fuzzy logic control system has been explored in the literature. In one case, the adaptive fuzzy proportional-integral derivative (PID) control, as an effective method of alternative control for envi- ronmental pollution in chemical reactions and for temperature control in process control industries was developed. The research was divided into two tasks (i) the design and analysis of the adaptive fuzzy logic PID controller, and (ii) design on both simulated and real-process data. The first involves the development of a design mehtod, implemented on a PC-based algorithm. The controllers' gains are self-tuned during the control process following the fuzzy logic IF-THEN rules, which are designed according to the classical adaptive control principles under the fuzzy logic environment.

For the second task, the method was first tested with computer simulated data, in comparison with both the conventional PID controller and the non-adaptive fuzzy PID controller. Simulation results have showed that the new design was overall better in the sense that it can handle highly nonlinear models and trade relatively rapidly changing set points also been tested using isothermal temperature control of an aluminum heat sink provided by the chemical company test sought to control isothermal temperature better or close to $\pm 0,02{ }^{0} \mathrm{C}$ the fuzzy PID controller has less overshoot and steady-state error. The next step in the research was to test and improve the design for chemical reaction data, which had more rapid changes in processing and, hence is much more difficult to control.

\section{Conclusions}

We presented a review of the literature on the EP research based on the key works of notable experts in the field. Our work incorporated four major parts: air, water, soil, and other aspect of the EP research. The conclusions drawn from this work may be summarised as follows. First, it seems that there is a significant interest of researchers and practitioners in experimental analysis of air, water and soil samples. The focus of this body of research has been the determination of concentration of pollutants. All these were measured in 3 states - solids, liquids and gases. In gases, for example, measurement is done on fraction by volume basis (e $\mathrm{g}$ $9 \mathrm{ppm}) \mathrm{CO}_{2}$. It could otherwise be done in mass per volume (e g 15 microgrammes per $\mathrm{m}$ lead in air). The measurement of concentration of liquids and solids are the same. Two main measures may be mentioned. The first is fraction by weight (e g 5 ppm lead), while the second may be mass per volume (e g $23 \mathrm{mg} / \mathrm{l}$ phenol in water).

There is a global trend seen in recent research on EP. Studies seem to relate EP with other variables. One common area of increasing interest is the sources of increased pollution. Three main sources are highlighted in the literature. Population growth is the first. The second one is increase per capital production and composition of goods. The third one relates to changes in goods and production methods.

From the literature, scholars have directly or indirectly pointed out the important characteristics of pollu- 
tion. However, the following points are distilled out. First, pollutants have long-distance movement. An example of this is the transport of DDT to Antarctica. Second is persistence in the environment. For example, pesticides take months to years to degrade. Also, radioactivity continues to gradually decrease for long periods. Third is synergism. This explains that the combined effects of two or more pollutants are more severe than or even qualitatively different from the individual effects of separate pollutants. Another characteristic of pollutants is its effects on the environment. This is perceived from different angles. We can consider its effects on plants, animals, materials, humans, and climates. For example, its effect on man could be viewed from (i) clinical effects by many pollutants; (ii) long latency period for some pollutants; and (iii) cancer mortality data in different countries.

Arsenic is an emerging issue, which challenge our way of experiment action in the EP research. Increasing occurrence of these pollutants are at an alarming rate. While this paper shows where scholarship is, and has been, we hope that the work makes a preliminary step in the creation of a new, more integrated theory, modelling and analysis of EP research. Future progress might arrive in a variety of ways. Perhaps, new theory, modelling, and analysis of EP problems is best conceived by a few scholars via thoughtful discussions over fine wine in front of a roaring fire. In that context, a key to intellectual progress is to capture the sustaining desire of the intellect for inquiry. A second approach is to see a collective focus among a group of interconnected scholars from different disciplines paying attention to major EP issues. We can envision scholars working on network and alliances to converge on a number of EP issues.

Research documentation, professional experience, reports, and intellectual discussions all suggest that the information explosion in the current decade will profoundly influence the EP research. Currently, computing is increasingly gaining the attention of researchers in the EP domain.

\section{References}

1. Antonescu, C.; Mateescu, C. Environmental pollution and its effects on honey quality, Roun. Biotechnol. Lett., 2001, 6(5), p 371-379. <http://bio.bio.unibuc.ro/biochemistry/ Enzimology/Vol 6, No 5-2001/010506-2001.pdf>

2. Abdel, A. S.; Metwally, E. Environmental pollution analytical study around inhabitant industrial near Cairo, Egypt. http://www.lanl.gov/BAER-onference/BAERCon-47pAbdel.pdf

3. Ahmed, R. Impact of environmental pollution in Rawalpindi - Islamabad, 24 $4^{\text {th }}$ WEDC Conference, 1998. $<$ http://www.lboro.ac.uk/departments/cv/wedc/papers/24/E/ ahmedr.pdf $>$

4. Diamantoukos, C. Estimating US environmental pollution liabilities by simulation, <http://www.casact.org/pubs/proceed/proceed00/00079.pdf $>$
5. Ganjidoust H. Caspian Sea environmental pollution prevention, 1998, <http://www.iies.org/english/training-conf/ conference/conf98-paper/pdf/ganjidoust.pdf>

6. Jost, F.; Quas, M. Population development and environmental pollution in Numbai - a case study, September, 2001. http://www.eco.uni-heidelberg.de/team/quaas/ mumbai-abstract.pdf

7. Lasut, M.T.; Kumurur, V. A. Pollution in marine coastal environment: A consideration for designing sustainable development of marine resources. <www.pustaka.bogor.net/ dtbaru/umm1334.htm>

8. Lee, K. Y.; Yoon Y. Y.; Yang M. K.; Shim S. K.; Seo B. K.; Chung Y. S. Investigation of environmental pollution with pine needles by NAA, Analytical Sciences, 17 (supplement) 2001.

9. Rao, M. 1996, The effect of published reports of environmental pollution on stock prices. Journal of Financial and Strategic Decision, 9 (1): p $25<\mathrm{http} / / / \mathrm{www}$.studyfinance. com/jfsd/pdffiles/v9n1/rao.pdf $>$

10. Sabir S. M., Khan S. W., Hayat I. Effect of environmental pollution on quality of meat in district Bagh, Azad Kashmir. Pakistan. Journal of Nutrition 2 (2): 2003, 98-101. $<$ http://www.pjbs.org/pjnonline/fin85.pdf $>$

11. Suga, N. A generalisation of the analysis of trade and environmental pollution, < http://www.econ.kyoto-u.ac.jp/ kokusai/sugaAbstract.pdf $>$.

12. Takahashi, R.; Zhang, X.; Onuro, I.; Kawabata, N.; Sinohara, H.; Ho, T. Present states and measure for environmental pollution from iron making industries in Shanxi Province in China, China - Japan International Academic Symposium Environmental Problem in Chinese Iron-Steelmaking Industries and Effective Technology Transfer Sendai, Japan, 6, 2000, March. < http://www.cir.tohoku. ac.jp/omura-p/symp_jc/01takaha.pdf $>$

13. Ulukanligil, M.; Seyrek, A.; Aslan, G.; Ozbilge, H.; Atay S. Environmental pollution with soil-transmitted Helminths in Sanliurfa, Turkey, <http://memorias.ioc.fiocruz.br/967/ 4245.pdf>

14. V. de Oliverira, C. R.; Barret, J. M.; V., de Oliveira, P. A.; Fialho, F. B. Intelligent decision support system applied to environmental pollution caused by swine manure, Agribuilding 2001, September 3-7, Campines, SP, Brazil. $<$ http://www.inf.ufsc.br/ 13c/artigos/Oliveira01.pdf $>$

15. Vavrova, M.; Gargosova, Z. H.; Sucman E. Impact of environmental pollution on contamination of locally grown nowghage, Acta Vet Brno, 2002, 71; p 389-400.

16. Milton, A. H.; Rahman, M. Environmental pollution and skin involvement pattern of chronic arsenicosis in Bangladesh, J. Occupational Health, 1999, 41; p 207-208.

\section{APLINKOS UŽTERŠTUMO PROBLEMŲ APŽVALGA}

\section{S. A. Oke}

S a n t r a u k a

I aplinkos orą išsiskiriančių teršalų kiekị labai lemia pramonès ekonomika. Tai patvirtina tyrimai aplinkosaugos ir sveikatos mokslų srityse. Darbe siekiama pateikti išsamią apžvalgą šia tematika. Iš esmès informatyvių straipsnių, sukurtų mode- 
lių, empirinių tyrimų ir pan. trūksta. Mūsų tikslas - paskatinti bei pletoti empirinius bei teorinius šios srities tyrimus. Svarbu sutelkti mokslini potencialą vykdant aplinkosaugini valdymą. Gautieji rezultatai ateityje bus reikalingi kitiems tyrinètojams ir mokslininkams. Būsimos studijos sutaupys milijonus dolerių plètojant naujus bei efektyvius aplinkosauginius metodus.

Raktžodžiai: teršalai, vanduo, oras, dirvožemis.

\section{ОБЗОР ПРОБЛЕМ ПО ЭКОЛОГИЧЕСКОМУ ЗАГРЯЗНЕНИЮ}

\section{С. А. Оке}

Р е $з$ ю м е

Количество загрязнителей, попадающих в окружающую среду, обуславливается уровнем развития промышленности. Это потвердили недавние исследования. Целью статьи было представить всесторонний обзор исследований по обсуждаемой тематике. В настоящее время ощущается дефицит информативных статей, освещающих глубину научных исследований в данной области. Цель статьи состоит в стимулировании внешних, эмпирических и теоретических исследований по обсуждаемой тематике. Результаты современных исследований позволят в будущем создавать новые высокоэффективные природоохранные методы.

Ключевые слова: загрязнители, вода, воздух, почва. 